\title{
ADDITION OF PROTEIC NITROGEN DURING ALCOHOLIC FERMENTATION FOR THE PRODUCTION OF CACHAÇA
}

Elisangela Marques Jeronimo ${ }^{1 *}$; Evelyn de Souza Oliveira²; Elson Luíz Rocha Souza ${ }^{3}$; Marcelo de Almeida Silva ${ }^{1}$; Gil Eduardo Serra ${ }^{4}$

${ }^{1}$ APTA - Depto. de Descentralização do Desenvolvimento - Pólo Regional do Desenvolvimento Tecnológico dos Agronegócios do Centro-Oeste, Rod. Deputado Leônidas Pacheco Ferreira, km 304, C.P. 66 - $17201-970$ - Jaú, SP - Brasil.

${ }^{2}$ UFMG - Faculdade de Farmácia - Depto. de Alimentos, Av. Antônio Carlos, 6627, Cidade Universitária Pampulha - 31270-901 - Belo Horizonte, MG - Brasil.

Ministério da Agricultura e do Abastecimento/DFA/MG - Posto de Análise de Bebidas de Andradas - Campus Experimental - C.P. 122 - 37795-000 - Andradas, MG - Brasil.

${ }^{4}$ UNICAMP/FEA - Depto. de Tecnologia de Alimentos, C.P. 6121 - Cidade Universitária Zeferino Vaz - Barão Geraldo - 13801-970 - Campinas, SP - Brasil.

*Corresponding author 〈elijeronimo@aptaregional.sp.gov.br>

ABSTRACT: Cachaça is the denomination of a typical and exclusive Brazilian spirit produced from the distillation of fermented sugarcane juice must. The objective of this study was to evaluate the effect of adding yeast extract to the sugarcane juice used for sugarcane liquor production, because for the artisanal process no studies are available on nitrogen addition nor beverage quality, involving nitrogen complementation. Results of previous studies in the laboratory scale showed that sugarcane juice complementation with proteic nitrogen can be a beneficial practice for yeast multiplication and cellular growth, and also for the improvement of fermentation yield and liquor productivity. In this pilot scale study, using recycled yeast, the addition of proteic nitrogen influenced positively the cell viability, confirmed the yeast recycling operation, and also reduced the fermentation time. The proteic nitrogen addition did not affect the sensory acceptance of the distillate, and did not change the contents of volatile compounds, indicating that assimilable forms of proteic nitrogen can be helpfull to improve the alcoholic fermentation for cachaça production.

Key words: yeast extract, cell viability, volatile compounds, sensory analysis

\section{ADIÇÃO DE NITROGÊNIO PROTÉICO DURANTE A FERMENTAÇÃO ALCOÓLICA DE CALDO DE CANA PARA PRODUÇÃO DE CACHAÇA}

\begin{abstract}
RESUMO: Cachaça é a denominação de uma típica e exclusiva bebida destilada brasileira produzida a partir da destilação do caldo fermentado da cana-de-açúcar. O objetivo deste estudo foi avaliar a adição de extrato de levedura no mosto de caldo de cana para a produção de cachaça, pois em processo artesanal não há estudos específicos sobre as características fermentativas da levedura assim como sobre a qualidade da bebida, envolvendo a complementação nitrogenada e em específico a aplicação de nitrogênio protéico. Os resultados obtidos em trabalhos anteriores, conduzidos em laboratório, indicaram que nas destilarias artesanais de aguardente a complementação protéica do mosto pode constituir uma prática benéfica para a multiplicação e crescimento celular do fermento e conseqüentemente, para a melhoria dos índices de eficiência, rendimento e produtividade do processo. Neste trabalho, conduzido em escala piloto, a adição de nitrogênio protéico influiu positivamente na manutenção da viabilidade celular, propiciando melhor qualidade do fermento reciclado e redução do tempo de fermentação. A adição de nitrogênio protéico no mosto não interferiu na aceitação sensorial da cachaça obtida, como também a análise dos componentes secundários não mostrou alteração consistente devido à aplicação de nitrogênio protéico. A complementação do mosto de caldo de cana com nitrogênio protéico em formas assimiláveis pela levedura revelou-se uma prática útil para a otimização do processo de fermentação alcoólica destinado à produção de cachaça.

Palavras-chave: extrato de levedura, viabilidade celular, compostos voláteis, análise sensorial
\end{abstract}




\section{INTRODUCION}

Cachaça is the denomination of a typical and exclusive Brazilian spirit produced from the distillation of fermented sugarcane juice must. It has an alcohol concentration of $38-48 \%\left(\mathrm{v} \mathrm{v}^{-1}\right)$ at $20^{\circ} \mathrm{C}$ and also exhibits higher alcohols, ethyl esters, aldehydes and organic acids that are responsible for the distinct aroma of the beverage (Brasil, 2003). The Brazilian production of cachaça is estimated in $1.3 \times 10^{9} \mathrm{~L}$ per year. The development of an image strongly linked to quality has been sought since long time by producers in Brazil. In addition to the traditional line of popular alcoholic beverages, producers also are investing in the development of products for more refined markets.

A pilot scale cachaça production has been studied by Oliveira et al. (2005) with different yeast strains; the licours obtained presented variation in secondary compound contents which, however, did not lead to significant differences in the sensorial attributes such as aroma, flavor and global impression.

The fermentation process must utilized by artisanal cachaça producers is that of single batches with sedimented recycled inoculum. The volume of sedimented inoculum normally corresponds to $20 \%$ of the volume of the fermentation vat. This inoculum consists of a mixed population of yeasts and bacteria, with about $3.6 \times 10^{9} \mathrm{CFU} \mathrm{m} \mathrm{L} \mathrm{m}^{-1}$ and $3.6 \times 10^{4}$ CFU m L $\mathrm{L}^{-1}$, respectively (Schwan et al., 2001). In cachaça artisanal distilleries the quality of the recycled yeast is usually compromised. Nitrogen complementation of the must can be a beneficial practice for cell multiplication and yeast growth with consequent increase in efficiency, yield and productivity indices of the process (Ribeiro et al., 1987). Addition of mineral nitrogen sources, a common practice, often shows controversial results (Vasconcelos, 1987; Ribeiro et al., 1987; Pinotti, 1991). Pulzatto (2000) has verified that the specific production of yeast cells $(\mathrm{Yx} / \mathrm{s})$ increased linearly with increasing protein nitrogen in a synthetic fermentation medium, as well as that the ethanol content in the wine and the fermentation yield were positively influenced.

The objective of this study was to evaluate the effect of adding yeast extract into sugarcane juice, on yeast cell viability maintenance, on the fermentation characteristics and also on the chemical and sensorial quality of cachaça in pilot scale fermentations using recycled sedimented yeast.

\section{MATERIAL AND METHODS}

\section{Microrganisms}

Fermentations were obtained using two Saccharomyces cerevisiae yeast strains, UFMG-A905 and UFMG-A1676, isolated from small cachaça destilleries.

\section{Inoculum preparation}

Strains were maintained in GYMP medium slants $(2 \%$ glucose, $0.5 \%$ yeast extract, $1 \%$ malt extract, $0.2 \% \mathrm{NaH}_{2} \mathrm{PO}_{4}$ and $2 \%$ agar), and to prepare the inoculum yeast strain cells were taken from the storage slant and inoculated in an activation medium (PDA - Potato Dextrose Agar) slants, $24 \mathrm{~h}$ before inoculation in the propagation medium. After $24 \mathrm{~h}$ yeast cells were aseptically transferred to six $250 \mathrm{~mL}$ flasks containing $100 \mathrm{~mL}$ sterile synthetic medium containing: $40 \mathrm{~g} \mathrm{~L}^{-1}$ glucose; $5 \mathrm{~g} \mathrm{~L}^{-1}$ potassium diphosphate; 5 $\mathrm{g} \mathrm{L}^{-1}$ ammonium chloride; $1.0 \mathrm{~g} \mathrm{~L}^{-1}$ magnesium sulphate heptahydrate; $1 \mathrm{~g} \mathrm{~L}^{-1}$ potassium chloride and $9 \mathrm{~g} \mathrm{~L}^{-1}$ yeast extract, at $\mathrm{pH}$ 6.0. Flasks were incubated at $32^{\circ} \mathrm{C}$ and $150 \mathrm{rev} \mathrm{min}^{-1}$ for $10 \mathrm{~h}$. Contents of each flask were then aseptically transferred to six flasks containing 1,200 $\mathrm{mL}$ of the same sterile culture medium, and incubated under the same conditions as before. Cell mass was separated by centrifugation, re-suspended in distilled water, washed twice and then used as the inoculum for the fermentation, under aseptic conditions. This entire procedure was repeated three times in order to obtain enough cellular mass (about 800 $\mathrm{mL}$ of a $10^{9}$ cells $\mathrm{mL}^{-1}$ suspension).

\section{Fermentation experiments}

Fermentations were conducted in a single batch system, with reutilization of yeast cells by sedimentation, in a pilot scale, that would simulate the artisanal cachaça production process. Sugarcane juice of the variety RB72454 was extracted in a previously desinfected grinder, sieved through a strainer to remove bagasse and then diluted with drinking water to $14{ }^{\circ}$ Brix. Treatments for each yeast strain consisted of production with and without yeast extract addition. As a proteic nitrogen source a yeast extract was used ( $5 \mathrm{~g}$ extract $\mathrm{L}^{-1}$, which is the equivalent to $3.28 \mathrm{~g}$ protein $\mathrm{L}^{-1}$ ).

Fermentation processes were conducted in stainless steel cylindrical tanks $(50 \mathrm{~cm}$ diameter and $54 \mathrm{~cm}$ height) with $40 \mathrm{~L}$ of must. The mean temperature of the must $\left(37^{\circ} \mathrm{C}\right)$ was controlled by a water circulating bath connected to the fermentation tank and mechanic stining, at $20 \mathrm{rpm}$. Up to seven consecutive fermentations were made, one initial fermentation inoculated with a suspension of pure yeast culture and up to six reutilizations of the yeast cells after sedimentation. 
The end of each fermentation was determined by the stabilization of the ${ }^{\circ}$ Brix reading up to zero (two equal and consecutive values in a one-hour period between samplings). At the end of the fermentations a wine sample was collected for determination of ethanol content and cell viability. Bacterial contamination was also monitored as part of the control of the process (Silva \& Junqueira, 1995). Wine was then left for two to three hours to decant the must of the yeast cells and a supernatant volume ( $35 \mathrm{~L})$ was taken from the fermentation tank (30 L were assigned for distillation). The distillations were performed with the wines obtained in fermentations $1,3,5$ and 7 . To the $5 \mathrm{~L}$ of decanted yeas that remained in the tank, about $3 \mathrm{~L}$ of potable water was added to dilute the wine and provide a better decantation. Then, the supernatant was separated, and the vat bottom was taken for the next batch with the recycled yeast. This decanted inoculum was treated with 50\% sulphuric acid, for $\mathrm{pH}$ reduction to $2.0-2.5$, with a residence period of one and half hours to avoid a possible bacterial growth.

\section{Distillation}

The distillation of each fermented broth was carried out in a copper still with a working capacity of $30 \mathrm{~L}$, equipped with a condenser and gas heater. The temperature of the sugarcane wine was controlled between 91 and $97^{\circ} \mathrm{C}$ to maintain the distilletion rate at about $1 \mathrm{~L} \mathrm{~h}^{-1}$. Distilled cachaça was collected in 700 $\mathrm{mL}$ glass bottles. Then, the fractions in the bottles were mixed in the same order in which they were obtained until reaching an average concentration of $43.5 \%\left(\mathrm{v} \mathrm{v}^{-1}\right)$, which has been established as the standard. The decision for the incorporation of the head fraction was based on the assumption that the drinks represented only by the heart fraction would be more similar in their composition and mask differences between the treatments.

\section{Analytical determinations}

Cell number and viability were determined in a Neubauer chamber, stained with eritrosin, according to Bonneu et al. (1991). Total nitrogen in the must and in the wine was determined by the Kjeldahl method, as described by Caldas (1998) and adapted by Jeronimo \& Serra (2003). Wine samples were distilled in an alcohol microdistiller for ethanol determination by the modified potassium dichromate method (Salik \& Povoh, 1993). For the determination of volatile acidity samples of cachaça were first steam distilled in an Enochimico Gibertini distilling apparatus and the distillate was titrated with $0.1 \mathrm{M} \mathrm{NaOH}$ using phenolphthalein as indicator (ABNT, 1997), and the ethanol concentrations were determined in a digital densitometer.
The secondary compounds were determined in the distillate by GLC using a Shimadzu model GC-17A gas chromatograph with automatic injection, a flame ionization detector and a DB-WAX capillary chromatographic column $(30 \mathrm{~m} \times 0.25 \mathrm{~mm} \times 0.25 \mathrm{~mm})$. The analyses were conducted under the following conditions: injector temperature $180^{\circ} \mathrm{C}$, detector temperature $190^{\circ} \mathrm{C}$, temperature programme for the column as follows, $40^{\circ} \mathrm{C}(5 \mathrm{~min}), 20^{\circ} \mathrm{C} \mathrm{min}^{-1}$ up to $120^{\circ} \mathrm{C}(1 \mathrm{~min})$, $30^{\circ} \mathrm{C} \mathrm{min}^{-1}$ to $180^{\circ} \mathrm{C}(1 \mathrm{~min})$, giving a total running time of $13 \mathrm{~min}$, the carrier gas was nitrogen, split mode injection of $1: 15$ and the sample volume of $1.0 \mathrm{~mm}$. The compounds were quantified using the external standard technique, the standards having been prepared in a $40 \% \mathrm{v} \mathrm{v}^{-1}$ ethanol solution (Oliveira e al., 2005).

\section{Sensory analysis}

For the treatments where cell recycling was possible, the cachaças obtained from the first and fifth (4th recycling) fermentations were submitted to sensorial acceptance tests using a 9-point hedonic scale (Stone \& Sidel, 1993). A panel of 30 judges, consumers of cachaça, evaluated the samples with respect to aroma, flavour and overall impresion. The evaluations were carried out in individual booths in transparent, colourless glass containers covered with a watch glass and codified with three digits. All the samples were presented in a monadic manner.

The sensory data were then submitted to ANOVA and Tukey test analyses (SAS Institute, 1993).

\section{RESULTS AND DISCUSSION}

In the presence of yeast extract the viability of the strain UFMG-A905 was higher (Figure 1) than in absence of protein nitrogen complementation (the deficient multiplication gave rise to insufficient cell mass, even in the first recycling). In the treatment with nitrogen complementation, the viability and cell mass were constantly high, up to the end of the experiment (six recyclings). The fermentation times were notably reduced in the treatment with higher amounts of total yeast cells, which are, in turn, correlated with protein nitrogen complementation (Figure 2). These positive results are in accordance with those found by Pulzatto (2000). Jeronimo (2004) also verified that the addition of protein nitrogen influenced positively the maintenance of cell viability, and can thus, provide better quality of the recycled yeast.

The yeast strain UFMG-A1676 presented a floating characteristic, with intense flotation beginning on the third fermentation. The mass of floating cells, certainly reducing the fermentation activity, was partially immersed, with one part above the wine surface form- 
Yeast UFMG-A905

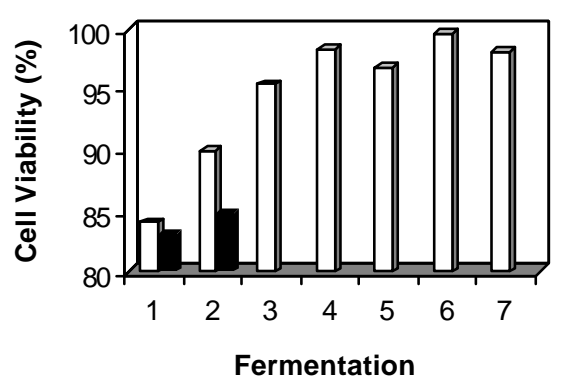

$\square$ with yeast extract addition

without yeast extract addition
Yeast UFMG-A1676

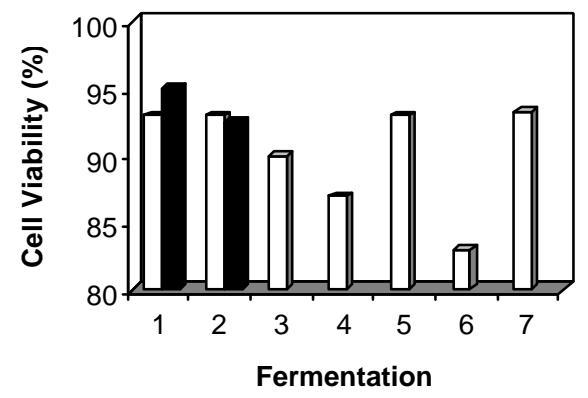

$\square$ with yeast extract addition

$\square$ without yeast extract addition

Figure 1 - Cell viability in the recycled inoculum in the experiments without and with yeast extract $\left(5 \mathrm{~g} \mathrm{~L}^{-1}\right)$. ${ }^{*}$ fermentation 1 (initial): inoculum prepared in laboratory; fermentation 2 to 7 : inoculum obtained from reutilization of the previous fermentation cells.

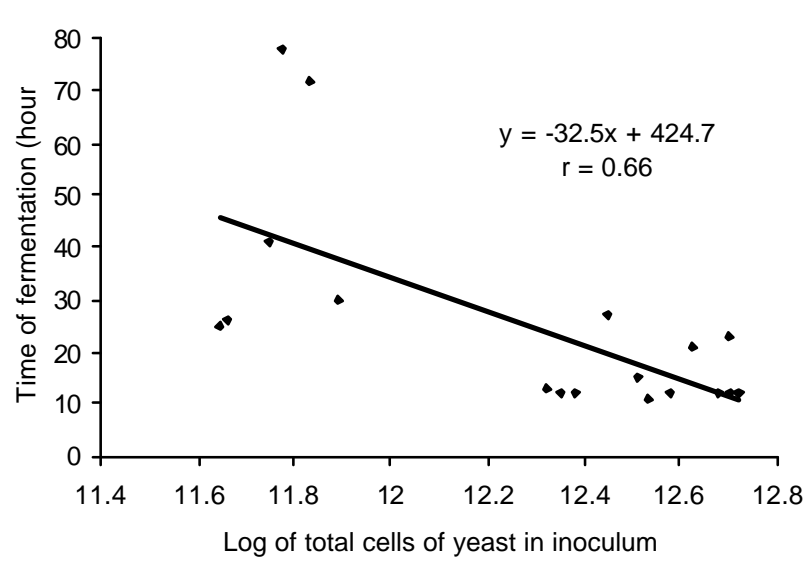

Figure 2 - Dispersion of the results of total yeast cell quantity (alive and dead) in inoculum and time of fermentation in sugarcane juice, of all of the results obtained in the experiments without and with yeast extract $\left(5 \mathrm{~g} \mathrm{~L}^{-1}\right)$.

ing a crust. When this mass was formed even by agitation of the tank and not disaggregating, the adopted procedure during recovery of the yeast was to discard it. Part of the cells also formed clumps that were firmly adhered to the internal surface of the vat, and thus, were not recovered together with the wine. Counting and microscopic observation showed that cells tended to be linked in groups of four to six units as in a necklace. However, even with a great loss of cell mass and reduction in the amount of yeast, addition of yeast extract maintained the viability and allowed fermentation to continue up to the 6th recycling, as planned (Figure 1). Under these conditions, the fermentation time was higher.

For strain UFMG-A905 the concentration of cells in the inoculum was kept around $10^{9}$ cells $\mathrm{mL}^{-1}$, however, if one considers that the volume of the decanted inoculum varied, the amount of total cells was reduced to values close to $10^{12}$ to $10^{11}$ when no yeast extract was added. In the fermentations with the floating yeast strain UFMG-A1676, a reduction of yeast total cells was also observed in the last recycling. When no yeast extract was added the yeast mass was greatly reduced and the fermentation time was longer than 70 hours already in the first recycling, for both yeast strains (Figure 2). This result without nitrogen protein complementation made the continuation of the recycling and of the experiment itself unfeasible.

The ethanol content in the wine varied from a minimum of 3.40 to a maximum of $7.68 \%$, and was always higher in the treatments with addition of yeast extract. Variation was limited to 5.90 to $7.68 \%$, when yeast extract was added, except for fermentations with the UFMG-A1676 strain, in which an intense flotation occurred (Figure 3). The content of soluble solids in the juice was kept at about $14 \%$ for all fermentations; this had been planed in order to obtain a better standardization for the fermentation conditions. The yield of the fermentation, represented by the amount of sugar present in the must which was transformed in to ethanol, was around 38 to $92 \%$, (data not shown). With proteic nitrogen addition (yeast extract) the yields varied from 65 to $92 \%$ approximately, except for the fermentations with intense flotation (UFMG-A1676 strain). Novaes (1995) reported that alcohol production yield in must spirit distilleries varies from 60 to $75 \%$ in relation to sugars present in the must.

The presence of proteic nitrogen in adequate amounts is a factor of great importance for cell multiplication; during yeast growth when nitrogen is assimilated, high growth rates can be achieved and the fermentative activity stimulated (Pulzatto, 2000). 
The original proteic nitrogen content of sugarcane juice in the must, varied from 55 to $67 \%$ of the total proteic nitrogen of the complemented must. This variation was due to the use of sugarcane stalks collected in different periods for the assays.

Yeast UFMG-A905

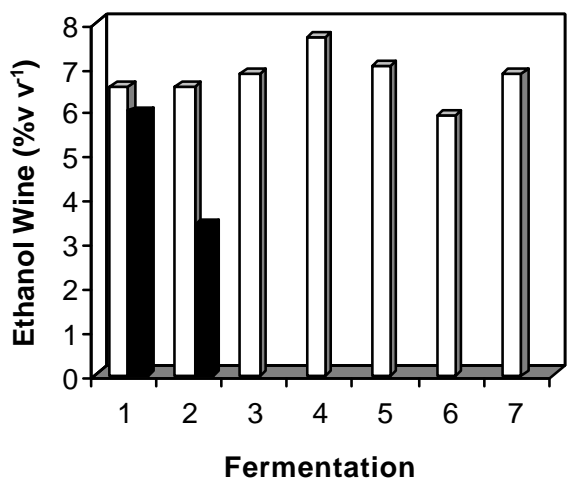

$\square$ with yeast extract addition

๘ with yeast extract addition
The monitored proteic nitrogen in the musts prepared with no proteic nitrogen varied from 4060 to 6850 mg $100 \mathrm{~mL}^{-1}$ (Table 1). The amount of yeast extract added was $3280 \mathrm{mg} 100 \mathrm{~mL}^{-1}$ of the proteic nitrogen.

\section{Yeast UFMG-A1676}

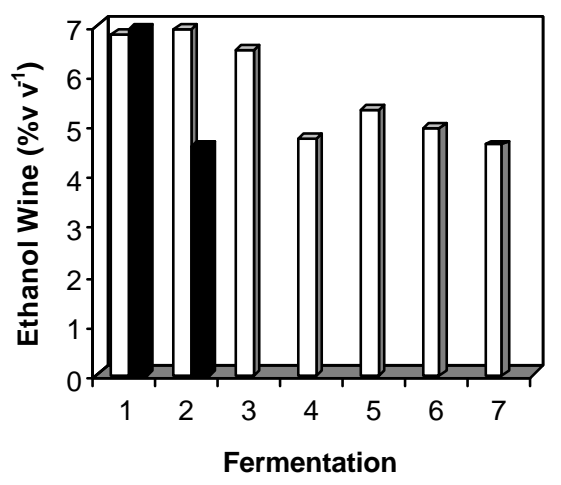

$\square$ with yeast extract addition

$\square$ with yeast extract addition

Figure 3 - Ethanol in wine in the experiments without and with yeast extract $\left(5 \mathrm{~g} \mathrm{~L}^{-1}\right)$. *fermentation 1 (initial): laboratory; fermentation 2 to 7 : inoculum obtained from reutilization of the inoculum prepared in previous fermentation cells.

Table 1 - Results for protein in must and wine and consumed, with and without proteic nitrogen addition in the yeast extract form $\left(5 \mathrm{~g} \mathrm{~L}^{1}\right)$.

\begin{tabular}{|c|c|c|c|c|}
\hline Fermentation* & Yeast & Must & Wine & Protein consumption \\
\hline \multicolumn{4}{|c|}{ - } & $\%$ \\
\hline \multicolumn{5}{|c|}{ WITHOUT YEAST EXTRACT ADDITION } \\
\hline 1 & 905 & 5330 & 410 & 92.3 \\
\hline $2 * *$ & & 5580 & 500 & 91.0 \\
\hline 1 & 1676 & 6590 & 200 & 97.0 \\
\hline $2 * *$ & & 5330 & 180 & 96.6 \\
\hline \multicolumn{5}{|c|}{ WITH YEAST EXTRACT ADDITION } \\
\hline 1 & 905 & 9110 & 1060 & 88.4 \\
\hline 2 & & 10130 & 2590 & 74.4 \\
\hline 3 & & 8100 & 3270 & 59.6 \\
\hline 4 & & 7840 & 2060 & 73.7 \\
\hline 5 & & 8100 & 2450 & 69.8 \\
\hline 6 & & 9870 & 3040 & 69.2 \\
\hline 7 & & 7840 & 2480 & 68.4 \\
\hline 1 & 1676 & 7340 & 1410 & 80.8 \\
\hline 2 & & 9620 & 1270 & 86.8 \\
\hline 3 & & 7840 & 1800 & 77.0 \\
\hline $4 * * *$ & & 8610 & 1920 & 77.7 \\
\hline 5 & & 8860 & 1950 & 78.0 \\
\hline 6 & & 7340 & 1950 & 73.4 \\
\hline 7 & & 8100 & 2530 & 68.8 \\
\hline
\end{tabular}

*fermentation 1 (initial): inoculum prepared in laboratory; fermentation 2 to 7 : inoculum obtained from reutilization of the previous fermentation cells; $* *$ ferment in conditions not adapted to procede recycling operation continuity; $* * *$ intense flotation of the yeast. 
When the yeast extract was added to the must the mean consumption was $74 \%$ of available nitrogen. The original proteic nitrogen in the sugarcane is almost totally consumed, meaning that it is present in a form assimilable by the yeast. From the yeast nutritional point of view the results show that the proteic nitrogen present in the juice is not enough for yeast nutrition during fermentation. So, adjustments in the levels of available nutrients are necessary to equilibrate the beneficial effects on cell viability and fermentative metabolism as well to produce adequate levels of secondary compounds during fermentation (Vasconcelos, 1987; Ribeiro et al., 1987; Abramov e al., 1994; Domínguez et al., 1997). The highest consumption of proteic nitrogen in the first fermentations of the experiments with added yeast extracts indicates that after consuming a higher amount of proteic nitrogen, the yeast reaches an adequate nutritional state and reduces its demand for proteic nitrogen in the subsequent fermentations.

The volatile acidity was the attribute that presented the largest variation- from 7 to $365 \mathrm{mg}$ of acetic acid $100 \mathrm{~mL}^{-1}$ of anhydrous alcohol. Cachaças with highest acidity also had high contents of ethyl acetate and reduction in propanol content. For the yeast strain UFMG-A905, the addition of yeast extract produced cachaças with individual volatile contents lower than the standards of the drink (Table 2). No evident alterations were perceived in relation to the treatment without addition. The last fermentation yielded a spirit with an acidity content about five to seven times higher than the others, five to six times more ethyl acetate content and two times less propanol. Although the differences are very marked the studied model does not allow to prove whether this effect is associated with the use of yeast extract or not.

For the yeast strain UFMG-A1676 the addition of yeast extract may be associated with the increase in acidity and ethyl acetate contents and reduction of propanol production (Table 3). This strain however was floating, and this characteristic could also be associated with the alterations in volatile compounds. Acidity is a quality factor of cachaça increasing the formation of esters which are important for the aroma, but excess acidity promotes undesirable and slightly aggressive flavor, lowering the drink quality (Cherubin, 1998). Alterations in acidity, ethyl acetate and isopropyl alcohol cause significant variations in the relation higher alcohols/non-alcohols and propanol/butanol, described by several authors as related to alcoholic beverage quality (Singer, 1966).

Table 2 - Alcohol content and volatile compounds in the cachaças obtained in the fermentationbatch with recycling of cells, with and without yeast extract addition; yeast UFMG-A905.

\begin{tabular}{|c|c|c|c|c|c|c|c|c|}
\hline Fermentation* & Yeast & Ethan $^{1}$ & $\mathrm{VolAc}^{2}$ & Acetal $^{3}$ & EilAc $^{4}$ & Prop $^{5}$ & Isob $^{6}$ & Isoam $^{7}$ \\
\hline & & $\% \mathrm{v} \mathrm{v}^{1}$ & \multicolumn{6}{|c|}{ - } \\
\hline \multicolumn{9}{|c|}{ WITHOUT YEAST EXTRACT ADDITION } \\
\hline 1 & 905 & 43.50 & 27.60 & 23.40 & 14.33 & 35.36 & 91.78 & 253.54 \\
\hline \multicolumn{9}{|c|}{ WITH YEAST EXTRACT ADDITION } \\
\hline 1 & 905 & 43.00 & 31.46 & 23.24 & 11.27 & 46.22 & 60.99 & 201.62 \\
\hline 3 & & 43.70 & 32.67 & 16.87 & 12.40 & 41.03 & 45.49 & 159.29 \\
\hline 5 & & 44.00 & 44.41 & 4.74 & 10.46 & 44.65 & 61.34 & 196.14 \\
\hline 7 & & 43.00 & 213.22 & 8.52 & 61.06 & 25.81 & 55.99 & 140.72 \\
\hline
\end{tabular}

${ }^{1}$ Ethanol $(\% \mathrm{v} \mathrm{v}-1) ;{ }^{2}$ Volatile acidity as acetic acid; ${ }^{3}$ Acetaldehyde; ${ }^{4}$ Ethyl acetate; ${ }^{5}$ Propanol; ${ }^{6}$ Isobutyl alcohol; ${ }^{7}$ Isoamyl alcohol.

Table 3 - Alcohol content and volatile compounds in the cachaças obtained in the fermentationbatch with recycling of cells, with and without yeast extract addition; yeast UFMG-A1676.

\begin{tabular}{|c|c|c|c|c|c|c|c|c|}
\hline Fermentation* & Yeast & Ethan $^{1}$ & $\mathrm{VolAc}^{2}$ & Acetal $^{3}$ & EilAc $^{4}$ & Prop $^{5}$ & Isob $^{6}$ & Isoam $^{7}$ \\
\hline & & $\% \mathrm{v} \mathrm{v}^{-1}$ & \multicolumn{6}{|c|}{ - } \\
\hline \multicolumn{9}{|c|}{ WITHOUT YEAST EXTRACT ADDITION } \\
\hline 1 & 1676 & 44.10 & 34.49 & 50.19 & 31.87 & 28.47 & 140.31 & 432.98 \\
\hline \multicolumn{9}{|c|}{ WITH YEAST EXTRACT ADDITION } \\
\hline 1 & 1676 & 44.00 & 34.16 & 13.28 & 26.18 & 54.32 & 67.24 & 250.53 \\
\hline 3 & & 44.00 & 211.79 & 10.76 & 67.55 & 24.25 & 71.63 & 189.34 \\
\hline 5 & & 43.70 & 364.58 & 13.69 & 134.01 & 15.56 & 66.00 & 174.95 \\
\hline 7 & & 39.10 & 361.34 & 20.81 & 56.53 & 19.95 & 76.44 & 224.41 \\
\hline
\end{tabular}

${ }^{1}$ Ethanol $\left(\% \mathrm{v} \mathrm{v}\right.$ ); ${ }^{2}$ Volatile acidity as acetic acid; ${ }^{3}$ Acetaldehyde; ${ }^{4}$ Ethyl acetate; ${ }^{5}$ Propanol; ${ }^{6}$ Isobutyl alcohol; ${ }^{7}$ Isoamyl alcohol. 
Table 4 - Average scores ${ }^{1}$ obtained for the cachaças in the acceptance test for the attributes aroma, flavour and overal impression.

\begin{tabular}{|c|c|c|c|c|}
\hline \multicolumn{2}{|c|}{ Cachaças } & \multicolumn{3}{|c|}{ Sensory Atributes } \\
\hline Fermentation & Yeast & Aroma $^{2}$ & Flavour $^{3}$ & Overall Impression ${ }^{2}$ \\
\hline \multicolumn{5}{|c|}{ WITHOUT YEAST EXTRACT ADDITION } \\
\hline 1 & 905 & $6.07 \mathrm{ab}$ & $5.72 \mathrm{a}$ & $5.74 \mathrm{ab}$ \\
\hline \multicolumn{5}{|c|}{ WITH YEAST EXTRACT ADDITION } \\
\hline 1 & 905 & $6.59 \mathrm{a}$ & $5.52 \mathrm{ab}$ & $5.83 \mathrm{a}$ \\
\hline 5 & & $6.07 \mathrm{ab}$ & $5.41 \mathrm{ab}$ & $5.61 \mathrm{ab}$ \\
\hline \multicolumn{5}{|c|}{ WITHOUT YEAST EXTRACT ADDITION } \\
\hline 1 & 1676 & $5.85 \mathrm{~b}$ & $5.15 \mathrm{ab}$ & $5.44 \mathrm{ab}$ \\
\hline \multicolumn{5}{|c|}{ WITH YEAST EXTRACT ADDITION } \\
\hline 1 & 1676 & $5.80 \mathrm{~b}$ & $5.33 \mathrm{ab}$ & $5.46 \mathrm{ab}$ \\
\hline 5 & & $5.15 \mathrm{c}$ & $5.02 \mathrm{~b}$ & $5.17 \mathrm{~b}$ \\
\hline
\end{tabular}

Contents of ethyl acetate were around 10.46 and $134.01 \mathrm{mg} 100 \mathrm{~mL}^{-1}$ of anhydrous alcohol (Tables 2 and 3). Oliveira (2001) found low contents of this compound (about 9.00 to $36.00 \mathrm{mg} 100 \mathrm{~mL}^{-1}$ anhydrous alcohol) in spirits produced in single batches with different yeast strains. Esters have a pleasant fruit scent and are considered important compounds for aroma in alcoholic beverages (Lehtonen \& Jounela-Erikson, 1983). Ethyl acetate is the must abundant ester of alcoholic beverages and in excessive amounts may confer an undesirable and disagreeable aroma (Maia, 1994).

The contents of higher alcohols, propanol, butanol and isoamyl alcohol belong to the major group of compounds responsible for the aroma and flavor of alcoholic beverages. These compounds are produced by yeasts from carbohydrates and amino acids, in amino acid biosynthesis and catabolism, respectively (Nykänen \& Suomailainen, 1983; Piggott et al., 1989). Propanol contents were higher in the treatments where organic nitrogen was added, especially for cachaças produced with the UFMG-A905 strain (Tables 2 and 3). High propanol contents are correlated with low quality spirits (Almeida \& Barreto, 1971), and also with good taste and global impression of artisanal cachaças (Silva, 2003; Oliveira et al., 2005).

Although some alterations in the content of volatile compounds are detected in the treatments with and without added proteic nitrogen the relationship between these variables cannot be characterized. Cachaças produced with the yeast UFMG-A905, did not lead to differences in sensorial attributes such as aroma, flavor and global impression (Table 4). The UFMG-A1676 yeast that has shown little favorable results due to its fermentation characteristics, also pre- sented in the sensory analysis equally unfavorable results (Tabela 4). Cachaças from the 5th recycling batch with yeast extract addition and produced with UFMGA1676, presented a very elevated ethyl acetate and acidity proportion (Table 3), as well as reduced proportions of alcohol. The elevated acidity of this cachaça is certainly the characteristic that was related with the low acceptance.

\section{CONCLUSIONS}

The adittion of proteic nitrogen in the must influenced positively the cell viability and ensured the yeast recycling operations. A reduction in the fermentation time was also observed.

Addition of proteic nitrogen did not affect the sensory acceptance of the distillate, and did also not change the contents of the volatile compounds, indicating that assimilable forms of proteic nitrogen can be helpfull to improve the alcoholic fermentation for cachaça production.

\section{ACKNOWLEDGMENTS}

To FAPESP for financial support and doctorate scholarship to first author.

\section{REFERENCES}

ABRAMOV, S.A; ÉFENDIEVA, D.A; KOTENTO, S.T. Effect of the growth medium on the protein content of the yeast Saccharomyces cerevisiae. Applied Biochemistry and Microbiology, v.30, p.225-227, 1994.

ALMEIDA, M.E.W.; BARRETO, H.H.C. Álcoois superiores em aguardente de cana por cromatografia gasosa. Revista do Instituto Adolfo Lutz, v.31, p.117-123, 1971. 
ASSOCIAÇÃO BRASILEIRA DE NORMAS TÉCNICAS - ABNT. NBR 13856: acidez titulável total, volátil total e fixa. São Paulo: ABNT, 1997.

BONNEU, M.; CROUZET, M.; URDACI, M.; AIGLE, M. Direct selection of yeast mutants with reduced viability on plates by erythrosine B. stainining. Analytical Biochemistry, v.193, p.225-230, 1991.

BRASIL. Decreto n. 4.851 do MAPA de 2 de outubro de 2003. Altera dispositivos do Regulamento aprovado pelo Decreto n. 2.314 , de 4 de setembro de 1997, que dispõe sobre a padronização, a classificação, o registro, a inspeção, a produção e a fiscalização. Diário Oficial da União, Brasília, 3 out. 2003.

CALDAS, C. Manual de análises selecionadas para indústrias sucroalcooleiras. Maceió: Sindicato da Indústria do Açúcar e do Álcool no Estado de Alagoas, 1998. 423p.

CHERUBIN, R.A. Efeitos da adição de benzoato de sódio na fermentação alcoólica para produção de aguardente de cana-deaçúcar (Saccharum spp). Piracicaba: USP/ESALQ, 1998. 70p. Dissertação (Mestrado).

DOMÍNGUEZ, V.E.L.; NELSON, D.L.; MAIA, A.B.R. Influência do fubá e do farelo de arroz sobre a formação de produtos secundários da fermentação alcoólica. STAB: açúcar, álcool e subprodutos, v.15, p.28-31, 1997.

JERONIMO, E.M.; SERRA, G.E. Adaptação do método de microkjeldahal para determinação de nitrogênio total em caldo de cana-de-açúcar In.: SIMPÓSIO LATINO-AMERICANO DE CIÊNCIA DE ALIMENTOS, 5., Campinas, 2003. Anais. Campinas: SBCTA, 2003.

JERONIMO, E.M. O nitrogênio protéico na fermentação alcoólica e sua influência na qualidade da cachaça. Campinas: UNICAMP/ FEA, 2004. 130p. Tese (Doutorado).

LEHTONEN, M.; JOUNELA-ERIKSSON, P. Volatile and nonvolatile compounds in the flavour of alcoholic beverages. In: PIGGOTT, J.R. Flavour of distilled beverages: origin and development. Englewood Cliffs: Prentice-Hall, 1983. p.64-78.

MAIA, A.B.R. Componentes voláteis da aguardente. STAB: açúcar, álcool e subprodutos, v.12, p. 29-34, 1994.

NOVAES, F.V. Produção e qualidade da aguardente de cana. Piracicaba: USP/ESALQ, 1995. 27p.

NYKÄNEN, L.; SUOMAILAINEN, H. Aroma of beer, wine and distilled alcoholic beverages. Berlin: Springer, 1983. 424 p.

OLIVEIRA, E.S. Características fermentativas, formação de compostos voláteis e qualidade da aguardente de cana obtida por linhagens de leveduras isoladas em destilarias artesanais. Campinas: UNICAMP/FEA, 2001. 135p. Tese (Doutorado).
OLIVEIRA, E.S.; CARDELLO, H.M.A.B.; JERONIMO, E.M; SOUZA, E.L.R.; SERRA, G.E. The influence of different yeasts on the fermentation, composition and sensory quality of cachaça. World Journal of Microbiology \& Biotechnology, v.21, p.707-715, 2005

PIGGOTT, J.R. Distilled beverage flavour: recent developments Chichester: Ellis Horwood, 1989. 352p.

PINOTTI, R.F. Quantificação do nível de nitrogênio nas etapas do processo de produção de álcool. STAB: açúcar, álcool e subprodutos, v.10, p.34-35, 1991.

PULZATTO, M.E. Fatores que influem na obtenção de biomassa de levedura seca (Saccharomyces cerevisiae) da fermentação alcoólica. Campinas: UNICAMP/FEA, 2000. 112p. Tese (Doutorado).

RIBEIRO, F.J.; LOPES, J.J.; FERRARI, S.E. Complementação de nitrogênio de forma contínua no processo de fermentação alcoólica. Brasil Açucareiro, v.1, p.26-30, 1987.

SALIK, F.L.M.; POVH, N.P. Método espectrofotométrico para determinação de teores alcoólicos em misturas hidroalcoólicas. In: CONCRESSO NACIONAL DA STAB, 5., Águas de São Pedro, 1993. Anais. Piracicaba: STAB, 1993. p.262-266.

SCHWAN, R.F.; CASTRO, H.A. Fermentação alcoólica. In: CARDOSO, M. das G. (Ed.) Produção de aguardente de canade-açúcar. Lavras: UFLA, 2001. p.45-47.

SILVA, C.L.C. Seleção de linhagens de Saccharomyces cerevisiae floculantes e linhagens não produtoras de $\mathrm{H}_{2} \mathrm{~S}$ e sua influência na qualidade da cachaça. Belo Horizonte: UFMG, 2003. 99p. Dissertação (Mestrado).

SILVA, N.; JUNQUEIRA, V.C.A. Métodos de análise microbiológica de alimentos. Campinas, 1995. cap.2, p.2129.

SINGER, D.D. The analysis and composition of potable spirits: Determination of $\mathrm{C}_{3}, \mathrm{C}_{4}$ and $\mathrm{C}_{5}$ alcohols in whisky and brandy by direct gas chromatography. Ânalyst, v.91, p.127-134, 1966.

STONE, H.; SIDEL, J.L. Sensory evaluation pratices. 2.ed. San Diego: Academic Press, 1993. 336 p.

VASCONCELOS, J.N. Influência da complementação de nutrientes nitrogenados e fosfatados sobre o processo de fermentação alcoólica industrial. Brasil Açucareiro, v.4/6, p.41-48, 1987.

Received December 11, 2006

Accepted September 03, 2007 